The Historical fournal, III, 2 (1960), pp. 125-143

Printed in Great Britain

\title{
II. BURKE AND THE ANCIENT CONSTITUTION- A PROBLEM IN THE HISTORY OF IDEAS
}

\author{
By J. G. A. Рососк \\ University of Canterbury, New Zealand
}

THE intention of this paper is to inquire into Burke's doctrine of traditionalism - as it may be termed-from a point of view not quite identical with that usually adopted. The aspect of Burke's thought thus isolated may or may not be the most important or the most characteristic, but it is the most familiar and that with which the student first becomes acquainted. Burke held - to summarize what may be found in a hundred text-books on the history of conservatism - that a nation's institutions were the fruit of its experience, that they had taken shape slowly as the result, and were in themselves the record, of a thousand adjustments to the needs of circumstance, each one of which, if it had been found by trial and error to answer recurrent needs, had been preserved in the usages and established rules of the nation concerned. He also held that political knowledge was the fruit of experience and that reason in this field had nothing to operate on except experience; from which it followed that, since the knowledge of an individual or a generation of individuals was limited by the amount of experience on which it was based, there was always a case for the view that the reason of the living, though it might clearly enough discern the disadvantages, might not fully perceive the advantages of existing and ancient institutions, for these might contain the fruits of more experience than was available to living individuals as the sum of their personal or reported experience of the world. It also followed that since the wisdom embodied in institutions was based on experience and nothing but experience, it could not be completely rationalized, that is, reduced to first principles which might be clearly enunciated, shown to be the cause of the institutions' first being set up, or employed to criticize their subsequent workings. There was, in short, always more in laws and institutions than met the eye of critical reason, always a case for them undiminished by anything that could be said against them.

All this is, of course, no more than elementary Burke, the first lesson learnt by every student of his thought. This paper is concerned with the way in which its presence in his thought should be historically explained. The account of political society here given is in a fairly obvious sense anti-rationalist: it endows the community with an inner life of growth and adaptation, and it denies to individual reason the power to see this process as a whole or to establish by its own efforts the principles on which the process is based. Burke's thought can, therefore, properly be set in opposition to any rationalist 
system of politics, which presents political society as based originally on the assent of individual minds to universal principles rationally discerned. Such systems, of course, abounded in the eighteenth century, and Burke opposed these where he met with them. But this does not of itself justify us in supposing that the historical origins of Burke's thought are necessarily to be found in a reaction against political rationalism, as if the latter had conditioned all political thinking before his time and some special explanation needed to be found of his breaking with it. Yet many studies of his thought have been and perhaps still are based upon some such presumption. Meinecke and Sabine, for example, both supposed that the thought of Burke must be regarded as an effect and consequence of Hume's critique of rationalism, ${ }^{1}$ and when Meinecke was constrained to admit that there was not enough evidence of Burke's having read Hume at the critical time, he fell back on the untestable hypothesis that Hume's teachings were 'in the air's and had infected Burke as a species of influenza. He was assuming that only some basic change of philosophical viewpoint could account for Burke's not conforming to a political rationalism which had hitherto dominated thought; and the assumption rests on a complex of misunderstandings which are still all too common among historians of ideas. We tend in the first place to assume that the ideas of a major thinker must be explained by co-ordinating them in a unified philosophy and discovering the common metaphysical or epistemological foundation on which they all rest; and we tend in the second place to simplify our field by the method of dialectical projection, by assuming that the thought of a particular period may be characterized as founded on certain common philosophical foundations and that the thought of the succeeding periods must be shown to have come into being as a result of some shift in these foundations. These methods are justified in some circumstances, but it is a misunderstanding to suppose that they must be adopted in all; and where we do not suppose this some other means must be found of offering historical explanations of a man's ideas. We now know, for example, that Locke's political thought is not a simple extension of his philosophy, but an explanation of contemporary political experience offered to his contemporaries in one, and not the only one, of the modes of discourse they were accustomed to adopt. ${ }^{3}$ The history of ideas may legitimately, though not exclusively, be viewed as the history of the modes of explaining the world and its behaviour which have from time to time existed. Burke says clearly of his doctrine of traditionalism that it is a way of thinking which existed in the England of his time and had existed for so long that it was itself traditional. In this paper an attempt will be made to

${ }^{1}$ F. Meinecke, Die Entstehung des Historismus (2nd edn., Munich, 1946), part I, ch. vi; G. H. Sabine, $A$ History of Political Theory (New York, 1945), ch. xxIx, 605-7, 612, 614, 618.

2 Meinecke, op. cit. 278.

3 P. Laslett(ed.), Fohn Locke: Two Treatises of Government (Cambridge, 1960), introduction, passim. 
see if he was right in this assertion, and if so what the consequences may be for the historical understanding of his thought.

We may conveniently begin with a passage from the Reflections on the Revolution in France which, like most of the quotations from Burke to be made in this paper, is familiar to all students and is cited here in an attempt to establish the proper context in which it may be understood.

The third head of right, asserted by the pulpit of the Old Jewry, namely, the 'right to form a government by ourselves', has, at least, as little countenance from any thing done at the Revolution, either in precedent or in principle, as the two first of their claims. The Revolution was made to preserve our antient indisputable laws and liberties, and that antient constitution of government which is our only security for law and liberty. If you are desirous of knowing the spirit of our constitution, and the policy which predominated in that great period which has secured it to this hour, pray look for both in our histories, in our records, in our acts of parliament, and journals of parliament, and not in the sermons of the Öld Jewry, and the after-dinner toasts of the Revolution Society. In the former you will find other ideas and another language. Such a claim is as ill-suited to our temper and wishes as it is unsupported by any appearance of authority. The very idea of the fabrication of a new government is enough to fill us with disgust and horror. We wished at the period of the Revolution, and do now wish, to derive all we possess as an inheritance from our forefathers. Upon that body and stock of inheritance we have taken care not to inoculate any cyon alien to the nature of the original plant. All the reformations we have hitherto made, have proceeded upon the principle of reference to antiquity; and I hope, nay I am persuaded, that all those which possibly may be made hereafter, will be carefully formed upon analogical precedent, authority and example.

Our oldest reformation is that of Magna Charta. You will see that Sir Edward Coke, that great oracle of our law, and indeed all the great men who follow him, to Blackstone, are industrious to prove the pedigree of our liberties. They endeavour to prove, that the antient charter, the Magna Charta of King John, was connected with another positive charter from Henry I, and that both the one and the other were nothing more than a re-affirmance of the still more antient standing law of the kingdom. In the matter of fact, for the greater part, these authors appear to be in the right; perhaps not always; but if the lawyers mistake in some particulars, it proves my position still the more strongly; because it demonstrates the powerful prepossession towards antiquity, with which the minds of all our lawyers and legislators, and of all the people whom they wish to influence, have been always filled; and the stationary policy of this kingdom in considering their most sacred rights and franchises as an inheritance. ${ }^{4}$

Now, before assuming that this passage must be explained by attributing to Burke possession of any general theory of man and society, we can take one by one the statements of which it consists, and see both what is being said in them and to what order of statement they belong. Burke is simultaneously advocating and making an appeal to history-to 'records, and acts of parliament, and journals of parliament' - and making a series of statements about

4 Burke, Reflections on the Revolution in France, in Works (Bohn's Libraries edn., 1901), II, 304-5. 
history; for he is saying that the practice of establishing the rules of political behaviour by an appeal to history conducted in this manner has been followed so regularly in the course of English history that it now constitutes a tradition of behaviour, a 'stationary policy' which he hopes and believes will be maintained in future. The Revolution of 1688 , he says, was conducted on the principle that there existed a body of ancient laws and liberties, and an ancient constitution guaranteeing them, and that all that was necessary in the conditions of that critical year was to reaffirm their existence; it was not conducted on the principle that under certain circumstances power 'reverts to the society' and the people have a right to 'erect a new form... as they think good'. ${ }^{5}$ Rights are not justified by abstract reason, but as an inheritance under. positive laws; but for this assertion to have validity, it is necessary that the positive laws be as old as, or older than, the rights which they substantiate and-almost-the society which contains them. From Coke to Blackstone, Burke observes, the great English lawyers have steadily maintained that this is in fact the case with English law: that the laws and liberties of England are rooted in Magna Carta, and the Charter of 1215 in a body of law very much more ancient than itself. Burke inspects this historical statement; he thinks it very largely accurate, but adds that the fact that it has so constantly been made is of greater significance than the accuracy of its contents, because it demonstrates that Englishmen have always been concerned to establish their rights by appeal to their own past and not to abstract principles. This habit of mind he considers the most important fact in the history of English political behaviour.

Burke is talking history; he is discussing both a traditional interpretation of English history and the part which that interpretation has itself played in shaping English history; and the historical facts to which he alludes are such as we may ourselves discern and describe in terms not unlike his own. There really did exist a habit of conducting political discussion in England 'upon the principle of reference to antiquity', upon the assumption that there existed an ancient constitution which was the justification of all rights and was itself justified primarily by its antiquity. The public and authorized theory of what had occurred in I688-9- that on which the houses of the convention parliament had been able to agree and which was contained in the public documents of the time-really did base its interpretation on the doctrine of the ancient constitution, far more than on the doctrines of contract, natural right and reason propounded by Sidney or Locke. The interpretation of history which that doctrine necessitated-involving the assertion that Magna Carta confirmed a charter of Henry I, which confirmed a charter of William I, which confirmed the laws of Edward the Confessor, which were themselves no more than a codification of law already ancient-had, as Burke remarks, been con-

5 The words in quotation marks are, of course, from the closing sentence of Locke's Second Treatise. Burke did not allude to that work in this part of the Reflections. 
stantly put forward by lawyers from Coke to Blackstone. It was consequently still a living issue in Burke's own time; he feels called upon to comment on its truth or falsity, and though he has enough historical detachment to feel interested primarily in its significance as a long-held belief, its truth as history seems to him to be well established. What he is saying, then, is not a piece of antiquarian's lore, but an account of contemporary practice. This is how we conduct our politics, he is saying; how we have always conducted them. He is not calling upon his contemporaries to return to a seventeenth-century habit of mind, but assuming that it is still alive and meaningful among them. It will be of some significance to our understanding of Burke's thought if we decide that he was right in this assumption.

The plot thickens and becomes more suggestive when we observe that the habit of mind denoted by the term 'ancient constitution' had alreadyduring the seventeenth century - produced and given expression to ideas very like those of Burke's traditionalism, and (though this is of less importance) that Burke had some opportunity of knowing this. It is the evidence for such an assertion that we must next review, though it involves some repetition of what has been said elsewhere. ${ }^{6}$

The doctrine of the ancient constitution received its classical formulation, though probably not its original conception, about the year 1600 . It was the work of common lawyers, and seems to have been shaped throughout by assumptions concerning the common law of England and deeply implanted in the mind of everyone trained in that study. These assumptions were first, that all the law in England might properly be termed common law; second, that common law was common custom, originating in the usages of the people and declared, interpreted and applied in the courts; third; that all custom was by definition immemorial, that which had been usage and law since time out of mind, so that any declaration of law, whether judgement or (with not quite the same certainty) statute, was a declaration that its content had been usage since time immemorial. These assumptions were now made the framework of an interpretation of history, one based on record, axiom and judgement rather than the statements of chroniclers and, therefore, containing at every turn the presumption that law was immemorial. It therefore became possible to believe that the whole framework of English law and (when that term came into use) the 'constitution'- meaning the distribution by law of powers of declaring and applying the law-had existed from the obscure beginnings of English history; from a time earlier than the earliest historical evidences. Legal history, read upon the assumptions which were native and instinctive to a common lawyer, became a series of declarations that the law was immemorial. In this way grew up an elaborate body of myths, maintained with great

- What follows is to some extent a development and reformulation of some points made in Pocock, The Ancient Constitution and the Feudal Law (Cambridge, 1957)-hereafter referred to as $A C F L$ - especially chs. II, VII and IX. 
tenacity by Englishmen of the seventeenth century and after, which taken together form the cult of the 'ancient constitution'. It has elsewhere been argued that the idea of immemorial law was one of the cardinal political ideas of Stuart England; and since it has been found to have appeared, based consistently on the same assumptions, in every major controversy and in the mind of every important political thinker from Coke to Locke, the hypothesis has received some verification. This, then, is the doctrine and the habit of mind which Burke describes as 'the stationary policy of this kingdom'.?

It may be further characterized as the habit of interpreting English politics and society not with the aid of any political theory designed for the explanation of society in general, but in the light of those assumptions about English society which were already contained in its most distinctive and characteristic body of rules. That body of rules was the common law and when English political thought committed the supreme insularity of assuming that English politics and history already contained all that was necessary to their understanding, and did not require to be studied in the light of any foreign law or universal principle, it was to the unique character of the common law that English thinkers were referring. Of this Burke seems to have realized something; in a passage ${ }^{8}$ closely following on the one already quoted, he speaks again of the age-old English practice of claiming their liberties

as an entailed inheritance derived to us from our forefathers, and to be transmitted by us to our posterity; as an estate specially belonging to the people of this kingdom without any reference whatever to any other more general or prior right.

He goes on to say that this practice is 'the happy result of following nature, which is wisdom without reflection and above it'.

Whatever advantages are obtained by a state proceeding on these maxims, are locked fast as in a sort of family settlement; grasped as in a kind of mortmain for ever. By a constitutional policy, working after the pattern of nature, we receive, we hold, we transmit our government and our privileges, in the same manner in which we enjoy and transmit our property and our lives. ${ }^{9}$

Now the way of thinking and behaving which Burke is here recommending was founded upon an identification of the rules and spirit of English society with the rules and spirit of the common law; and the common law had taken shape as a law of real property. It cannot be quite coincidental that in these passages Burke is talking of the advantages which accrue when a people lay claim to their liberties on exactly the same principles as those on which they inherit their estates. From the words which have just been quoted he goes on without interruption to embark upon the famous passage which runs:

The institutions of policy, the goods of fortune, the gifts of Providence, are handed down, to us and from us, in the same course and order. Our political system is placed in a just correspondence and symmetry with the order of the world, and with

7 For the foregoing see $A C F L$, ch. II and generally.

Burke, op. cit. 306 .

? Burke, op. cit. 307 . 
the mode of existence decreed to a permanent body composed of transitory parts; wherein, by the disposition of a stupendous wisdom, moulding together the great mysterious incorporation of the human race, the whole, at one time, is never old, or middle-aged, or young, but in a condition of unchangeable constancy, moves on through the varied tenour of perpetual decay, fall, renovation and progression.

This has many times been cited as evidence of Burke's vision of society as an organic community, not composed atomistically of self-regarding individuals; and so indeed it is. But if we seek for the historical genesis of these thoughts, may it not lie in the chain of association formed by the words 'entail', 'family settlement', 'mortmain,' 'incorporation', which occur in that order in the passages that have been quoted? 'In this choice of inheritance', Burke says, 'we have given to our frame of polity the image of a relation in blood'.10 That is, we have made the State a family; but have we not done so by constituting it a family in the sense in which a family is a relation in law? By entailing our inheritance of liberties we have established a family settlement, based upon a mortmain; and it is when this is done, not in virtue of the tie of blood solely, that the family becomes an immortal corporation. We have made the State not only a family, but a trust; not so much a biological unity, or the image of one, as an undying persona ficta, which secures our liberties by vesting the possession of them in an immortal continuity. And all this has been done by the simple device-the most superb of all legal fictionsof identifying the principles of political liberty with the principles of our law of landed property. Burke sees this as an act conformity with the order of nature, and it is not the intention of this paper to deny the importance which his conception of nature had in the formation of his political philosophy. But the above passages may at the same time be cited as evidence that he had achieved a genuine historical insight into the character of English political thinking. He says, quite explicitly, that it is the greatest accomplishment of our thought to have based our claim to liberty on an idea drawn from the law of real property; and historical inquiry seems to confirm that it was the influence of that law on political thought which had given rise to the very English way of thinking and behaving which Burke accurately describes, and with which he identifies himself.

It has now to be shown that a doctrine of traditionalism, very much akin to Burke's own, grew out of the concept of the ancient constitution. To do this we need to remind ourselves that this concept was founded on the identification of English law with custom, and that the term custom had more than one connotation for common lawyers. Primarily, it implied that all that was custom was immemorial; but this need not-though it often did-imply a static and unchanging content. A second implication, of no less importance than the first, was that custom was constantly being subjected to the test of experience, so that if immemorial it was, equally, always up to date, and that 
it was ultimately rooted in nothing other than experience. We may put the point in the words of Sir John Davies, James I's Attorney-General for Ireland, who had written 'the Common Law of England is nothing else but the Common Custome of the Realm'. ${ }^{11}$ The essence of this law was in immemorial usage; it consisted of a series of 'reasonable acts once done', which, having been found 'good and beneficial to the people', had been repeated 'without intertuption time out of mind' and so had become a law recognized, declared and recorded as such in the courts of common law. The act itself was nothing but a response to experience, and the test by which it had been found good and beneficial nothing but further experience. From about 1600 , if not from much earlier, this concept lay at the heart of English thinking about law and exerted a potent influence on thinking about politics and society. It will be observed that though Davies refers to the act in usage as 'reasonable', he nowhere suggests that its rationality was the proof that it was good and beneficial, still less that reason gave it the force of law. No doubt he regarded usage and experience as in some sense or other rational behaviour, but he does not equate law with reason; and both in his writings and in Coke's, signs may be found that common lawyers were already disposed to draw a distinction between the wisdom of the law, founded in experience, and the reflective reason of individuals, which they regarded as a different instrument designed to produce different and perhaps lesser results.

Two famous quotations from Coke may make the point for us. The first is from his notorious and variously reported interview with James I.

Then the king said, that he thought the law was founded upon reason, and that he and others had reason as well as the judges: to which it was answered by me, that true it was, that God had endowed his Majesty with excellent science, and great endowments of nature; but his Majesty was not learned in the laws of his realm of England, and causes which concern the life, or inheritance, or goods, or fortunes of his subjects are not to be decided by natural reason, but by the artificial reason and judgment of law, which law is an act which requires long study and experience before that a man can attain to the knowledge of it. ${ }^{12}$

The other is from Calvin's Case:

our days upon the earth are but as a shadow in respect of the old ancient days and times past, wherein the laws have been by the wisdom of the most excellent men, in many successions of ages, by long and continuall experience, (the trial of light and truth) fined and refined, which no one man, (being of so short a time) albeit he had in his head the wisdom of all the men in the world, in any one age could ever have effected or attained unto. ${ }^{13}$

In both these passages Coke's contention appears to be the same. Philosophic reason could not by its own efforts reconstruct the law, because the

11 Davies, Irish Reports (1614-London edn. of 1674), preface.

12 Coke, Twelfth Reports, Prohibitions del Roy ( 12 Co. Rep. 65).

13 Coke, Seventh Reports, Calvin's Case (7 Co. Rep. 3 b). 
law's origin is not in any philosophical assumption but in a multitude of particular decisions. The only way to know the law, therefore, is to know the law, by becoming acquainted with the innumerable decisions and digests of decisions which it contains. Selden believed that a deeper understanding of the law could be attained by historical knowledge of the circumstances in which the various decisions had been taken, but Coke gives no sign of believing even that; for him, there was little to be known about the history of the law except that it was immemorial. No one man, by taking thought, could reproduce the infinitely complex train of experiences and decisions which had led the law to be what it was; and Coke seems also to be denying that there exist any means whereby the intellect can, by laying down axioms, assumptions or universal propositions, reproduce the law as a process of reasoning. The law, in short, cannot be reduced to general principles, or scientific laws, and their consequences; and in this very lawyer-like proposition we seem to have one origin of the long tradition of sceptical and conservative empiricism in English social thought. If so, the long outmoded concept of immemorial law has done much to make our thought what it is today; for it was the principle that the law was immemorial that made common lawyers realize that its origin was not in men's assent to universally acceptable propositions, but in 'one emergency following upon another as wave follows wave; only one great fact with respect to which, since it is unique, there can be no generalizations' ${ }^{14}$

It seems, then, that an empirical and traditionalist way of thought, sceptical of systematic reason, formed part of the intellectual equipment of common lawyers and was grounded on the same assumptions as belief in the ancient constitution. With the next step in the story, we arrive at the first direct clash in the history of English thought between this outlook and the political rationalism which we learn from Burke to regard as its antithesis. A few years after the Restoration Thomas Hobbes completed his Dialogue of the Common Laws, and in this work set out to deny that the law of England was either immemorial custom or Coke's 'artificial reason'. ${ }^{15}$ To Hobbes, consistent in this dialogue with the ideas of his major political works, society was composed of and by individuals employing their 'natural reason', which dictated to the individual that certain things must be done for his own preservation and, later, that certain things must be done by all for the preservation of all. To enforce the doing of these things a sovereign was set up, and doing them became a law for all when established as such by his command. But he did not possess more 'natural reason', let alone reason of another sort, than that possessed by other men, and it was by the natural reason that he shared with his subjects that the laws he enjoined were seen to be necessary. All that was artificial about the sovereign was his power to command. Any doctrine of an artificial reason, known only to professionals as their craft mystery and

14 H. A. L. Fisher's preface to his History of Europe, r946, v.

${ }^{15}$ Hobbes, English Works (ed. Molesworth, I839-45), vi, 5-7, I4-I 5, 62-3. 
ultimately inscrutable to reflective reason, appeared to Hobbes dangerous alike to the human mind and to the stability of the state, as tending to monopolise power in the hands of Bentham's Judge and Co. He therefore found it necessary to maintain that law was the product of natural reason and should be such as any intelligent individual might frame for himself; and in so far as the reason he spoke of was scientific, arguing logically from universal truths, Hobbes maintained the possibility of a social science. This was the ground on which he was met by Chief Justice Sir Matthew Hale-though Hale's reply remained unfinished and unpublished ${ }^{16}$ - and both here and in his History of the Common Law, Hale set out in opposition to individualistic rationalism an empirical and traditionalist view of the law which can be shown to be founded on the common-law concept of custom.

Hale was a philosopher as well as a judge-though his philosophy was as case-made as his law - and he began his reply to Hobbes with epistemological considerations. Reason, he said, was the faculty of discerning the necessary connexions between things, and a man became expert at law, medicine or some other form of learning as he applied this faculty to different classes of things; so that, though the same faculty of reason might be at work in all cases, a man expert in one field might be hopelessly inept in another-it was the things of which a man had experience that determined the character of his knowledge, and the notion of a naturally reasonable individual who became, simply by applying his reason, good at making and applying laws must therefore be dismissed. ${ }^{17}$ Law was a matter of applied morals, and this field was a specially complicated one; for the fact that a man was expert at moral philosophy, that is at discerning the connexions between moral ideas, was no guarantee of his success in applying these ideas to practical decisions. This was a class of problem in which Hale thought a power of discerning necessary connexions likely to be of very little use, for he was above all impressed with the complexity and instability of the human context in which such decisions had to be taken, and was disposed to regard each decision not as the recurrence of a regular phenomenon but as something unique. Two quotations may help to make his thought clear.

... it is a thing of greatest difficulty, So to Contrive and Order any Lawe that while it remedyes or provides against one Inconvenience, it introduceth not a worse or an equall...the texture of Humane affairs is not unlike the Texture of a diseased bodey labouring under Maladies, it may be of so various natures that such Phisique as may be proper for the Cure of one of the maladies may be destructive in relation to the other, and the Cure of one disease may be the death of the patient. ${ }^{18}$

${ }^{16}$ It is printed as an appendix (pp. 499-5I3) to vol. v of W. S. Holdsworth's History of English Law. A hint at the date of its composition may be found in John Aubrey's letter of 3 Feb. 1673 , in which he seeks to further the publication of a work on law by Hobbes, saying that Hale 'has read it and much mislikes it' (Brief Lives, ed. Clark, 1898, I, 394). It is still very improbable that Aubrey is referring to the Elements of Law, as some most scholars have concluded.

17 Holdsworth, op. cit. v, 501-2. 18 Ibid. 503. 
This instability of context affected not only the practical but the moral problem:

...every Morall Action is or may be diversified from another by Circumstances which are of soe greate an Influence into the true nature and determination of Morall Actions that they very frequently specifically difference Actions that are materially the Same, and give such Allayes and abatements or advances and improvements to them that Scarce two Morall Actions in the world are every way commensurate. And these Circumstances are Soe various and their Influx into Morall Actions so different and Soe difficult to be discerned, or adequately estimated, that the makeinge of Laws touching them is very difficult. ${ }^{19}$

Here, plainly, we have the social philosophy of a judge, a man accustomed to viewing each moral problem on its merits as it comes before him, and to viewing it as entangled in the endlessly complex web of practical social reality. This alone might explain Hale's disposition to view each problem as a unique complexity and to doubt whether there exist universally valid patterns of thought with which natural reason may legislate for society-to doubt, in short, the efficacy of a social science. But we cannot leave out of account the further fact that Hale was accustomed to dealing with such problems with the aid of a law which already insisted that there were no universally valid rules, only accumulated experience, and that the only outcome of experience was a precedent which never achieved finality as a universal rule. It is law of this kind which Hale goes on to recommend as an artificial reason more effective and reliable than Hobbes's natural reason. Directly after the words last quoted, we find him advocating reliance on ancient law in preference to the dictates of individual reason, and his argument for doing so comes in a double form. In the first place, he argues that experience does what reason cannot do-it finds out the 'conveniences and inconveniences' that attend the operation of a particular law, which the complexity and instability of the social context render it impossible 'for the wisest Councill of Men att first to foresee'. Secondly, and in consequence of this, he argues that ancient laws very often defy our criticisms, for the reason that while we have the law itself we no longer know the circumstances in which, or the reasons for which, it was originally made. Therefore we cannot criticize those reasons; but the mere fact that the law survives furnishes a presumption, not only that the law was originally good, but that it has adequately answered the needs of all the situations in which it has subsequently been invoked. There is a further presumption that it will adequately solve our problem, even though to our intellects, evaluating the problem and the law, it may not appear so.

From all this it seems to follow that the law is inscrutable; it is reasonable, Hale says, but our reason cannot tell why. Historical reconstruction cannot tell us, since the law itself may be the only evidence we have concerning its history; philosophical consideration cannot tell us, because the law is nothing

19 Ibid. 504. 
but a record of particular decisions and is not founded on any universal rational propositions. It can only be known as a collection of particulars.

Now if any the most refined Braine under heaven would goe about to Enquire by Speculation, or by reading of Plato or Aristotle, or by Considering the Laws of the Jewes, or other Nations, to find out how Landes descend in England, or how Estates are there transferred, or transmitted among us, he wou'd lose his Labour, and spend his Notions in vaine, till he acquainted himselfe with the Lawes of England, and the reason is because they are Institutions introduced by the will and Consent of others... the Positions and Conclusions in the Mathematicks have more Evidence in them, and are more Naturally Seated in the minde than Institutions of Laws, which in a greate measure depend upon the Consent and appointment of the first Institutors. ${ }^{20}$

The law does not consist of first principles and their logical consequences, the necessary connexions between which can be known by reason. It consists of a series of particular decisions, each of which was framed in circumstances no longer known and has been tested by experience in circumstances which may similarly have been forgotten. All that need-very often all that canbe known of it is that it has survived an indefinite number of such tests, and this is enough to create a presumption that it is more efficacious than our intellects can comprehend. Such is Hale's reply to the rationalism of Thomas Hobbes, a reply which visibly gives expression to the social philosophy of the common law and is essentially a development of common-law assumptions concerning the law and its workings. Only an immemorial customary law could satisfy Hale's requirements or give birth to his ideas, for if law were founded on the decisions of known men in recorded circumstances it could be evaluated and criticized both on rational and on historical grounds and would lose the ultimate inscrutability with which Hale, a sceptical traditionalist, is seeking to invest it. There is little about custom in the reply to Hobbes, but in his History of the Common Law ${ }^{21}$ Hale worked out, at length and with subtlety, a view of law as immemorial custom in perpetual adaptation.

On his interpretation of immemorial law, it was not necessary that it should have retained its present content since time beyond memory, for law consisted solely in a series of responses to particular exigencies and what rendered it immemorial was not the stability of its content but the continuity (since time beyond memory) of the process of adapting old precedents to new situations. As this process continued the old precedent became, by degrees and generally insensibly, both refined and enlarged, until it took on a meaning beyond anything those who first established it could have intended. Therefore, one would not seek to know the meaning of a law by going back

20 Holdsworth, op. cit. v, 505 .

21 This too was published posthumously in 1714 . Since Hobbes's Dialogue was unpublished until 1682 , the whole story of the contact between these two minds, of some importance to the understanding of the recurrent themes in English political thought, was overlooked until Holdsworth and Pollock brought it to light. 
to the circumstances of its first institution, and indeed in most cases neither these nor the subsequent stages of its development could be accurately known. Hale united a subtle sense of historical growth with a high degree of scepticism as to the possibility of historical knowledge, and in this as in all else he was a true common lawyer in his thought. He regarded the records of the law as very nearly all the evidence existing concerning the history of the law, and these records, as he knew, did not often rehearse the circumstances in which they had been made and were in essence little more than a series of declarations of what the immemorial law was, through which nevertheless ran a thread of almost imperceptible change. Hale, therefore, despaired of knowing when any particular point in the law had originated, or of recovering its original meaning from its successive reformulations, or of establishing what the state of the law as a whole had been at any moment in time past; nor did he think that this mattered. ${ }^{22}$ To him the law was in flux, constantly being restated by people, parliament and judges in response to their immediate practical needs, and what was of importance was that they had chosen to do this rather by restating old decisions than by creating new out of their rational estimate of each situation as it arose. Because they operated in this manner the law was perpetually in change and you could neither analyse what it was nor reconstruct its history; but they were constantly drawing on and applying the accumulated experience of their ancestors, even though they could not explain what it was nor demonstrate its rationality. Hale repeatedly uses the image of law as a river, and what matters to him is not the analysis of the water it contains but the unchecked continuity of its flow. Society constantly produces law; doing this by refining on old precedents, it accumulates a wisdom which is rooted in experience and never rationally demonstrable or capable of analysis into its elements. It is the fact that it is the record of society's experience that makes law immemorial.

Such is Sir Matthew Hale's philosophy of the common law; its kinship with the traditionalism we ascribe to Burke should be evident. The question now to be settled is that of the connexions between Burke and the common-law thought of the seventeenth century, and here we may begin by reminding ourselves that Burke alluded to the belief in an immemorial constitution as a thing well known to himself and his readers, of peculiar importance to the understanding of seventeenth-century constitutional history, and as a way of thinking still alive in his own time. Burke was then aware of common-law thought both as a phenomenon of the seventeenth century, and as a phenomenon of the eighteenth; and it may be worth commencing under the former head and investigating his knowledge of Hale as the common-law theorist whose ideas most resembled his own. There is no reason to suppose that he knew the manuscript reply to Hobbes, though there were copies in the Harleian MSS.

${ }^{22}$ The key passage for the above interpretation of Hale's thought is in ch. IV of his History of the Common Law (2nd edn., 17r6, 57-65). See also ACFL, 174-8. 
and in the collection of Francis Hargrave $;^{23}$ but the History of the Common Law was one of the standard books of the eighteenth century, and in an early work from Burke's hand we have his opinion of it. That opinion is unfavourable, but illuminating. There is a fragment, which may date from about Burke's thirtieth year, known under the title of Essay towards a History of the Laws of England; after remarking that few attempts have been made to provide such a history, he continues:

Lord Chief Justice Hale's History of the Common Law is, I think, the only one, good or bad, which we have. But with all the deference justly due to so great a name, we may venture to assert that this performance, though not without merit, is wholly unworthy of the high reputation of its author: the sources of our English law are not well, nor indeed fairly, laid open; the ancient judicial proceedings are touched in a very slight and transient manner; and the great changes and remarkable revolutions in the law, together with their causes, down to his time, are scarcely mentioned.

Of this defect I think there were two principal causes; the first, a persuasion hardly to be eradicated from the minds of our lawyers, that the English law has continued very much in the same state from an antiquity to which they will allow hardly any sort of bounds. The second is, that it was formed and grew up among ourselves; that it is in every respect peculiar to this island; and that if the Roman or any foreign laws attempted to intrude into its composition, it has always had the vigour to shake them off, and return to the purity of its primitive constitution.

These opinions are flattering to national vanity and professional narrowness.... we have been, and in a great measure still are, extremely tenacious of them. If these principles are admitted, the history of the law must in a great measure be deemed superfluous. For to what purpose is a history of a law, of which it is impossible to trace the beginning, and which, during its continuance, has admitted no essential change? Or why should we search foreign laws, or histories, for explanation or ornament of that which is wholly our own; and by which we are effectually distinguished from all other countries? Thus the law has been confined, and drawn up into a narrow and inglorious study... which deduced the spirit of the law, not from original justice or legal conformity, but from causes foreign to it, and altogether whimsical... . the truth is, the present system of our laws, like our language and our learning, is a very mixed and heterogenous mass; in some respects our own; in more borrowed from the policy of foreign nations and compounded, altered and variously modified, according to the various necessities, which the manners, the religion and the commerce of the people have at different times imposed. ${ }^{24}$

Here the young Burke, perhaps not long out of the Middle Temple, shows the same vigorous awareness of the tradition of common-law thought and belief in the ancient constitution as he was to display in the Reflections, thirty years later, when he wrote: 'In the matter of fact, for the greater part, these authors appear to be in the right; perhaps not always.' But here his

23 Holdsworth, op. cit. v, 499.

${ }^{24}$ Burke, Works (Bohn's Libraries edn., London, George Bell and Sons, 1877), vi, 413-16. This fragmentary study is usually exempted from the controversy concerning the authenticity of the Essay towards the Abridgment of the English History, with which it has been printed. 
attitude is hostile, and his criticism is founded on the quite accurate perception that if the law is absolutely unique and absolutely immemorial, there is nothing about its history that can usefully be said. In one sense, he was being unfair to Hale, who had many times denied that an immemorial law meant a law whose content never changed and had asserted, in words foreshadowing Burke's own, that the law had been transformed utterly in the course of its history. But the difference between Hale and Burke lies deeper: Burke here is asserting, what Hale had virtually denied, that the course of change in the law can be historically explained by relating it to the operation of factors outside the law and independently known. To Hale a legal decision was a response to some momentary situation, of which as a rule no record was preserved other than the decision to which it had given rise, so that there was little prospect of historical reconstruction. Burke is visibly of the opinion that there is more evidence about the history of the law than the law by itself supplies, and the crucial point of his difference with the common-law school lies here. In making this point, we should note that he speaks with two distinguishable voices. His insistence that the law is derived in large part from foreign nations may have been drawn from Spelman-whom he discusses $^{25}$ - or the other seventeenth-century scholars who had investigated the Germanic, feudal or Norman origins of much English law. But a certain emphasis should be given to Burke's use of the words 'the spirit of our laws' and his reference to 'the various necessities, which the manners, the religion and the commerce of the people have at different times imposed'. Here is thoroughly eighteenth-century language: the idea that peoples or their institutions possess a 'spirit', or historical character, which may be understood by relating it to just such things as 'the manners, the religion and the commerce of the people', might come direct from Montesquieu or any of the Scottish historical sociologists with whom Burke was later to be acquainted. The words prefigure the Speech on Conciliation with America and the orator who was to depict the 'spirit' of the American colonists in as impressive a passage as eighteenth-century historiography contains. At this point in his thought, then, Burke is thoroughly of his age in believing that laws can be understood by reference to the operation of general social factors, and he rejects the empiricist mystique of the immemorial partly on these grounds. He implies clearly that the history of the law can be made intelligible.

But he knew, when writing this early essay, that if the law were truly immemorial and as Hale had described it, the reverse was true and its condition in the past could not be reconstructed. He therefore understood on what his position was based, and what its contrary was, and this helps us to understand the fact that in 1782 we find him reversing it and returning to a doctrine very like Hale's. In May of that year he composed but did not

25 Burke, loc. cit. 4r4. 
deliver the speech ${ }^{26}$ On a Motion Made in the House of Commons... for a Committee to Enquire into the State of the Representation of the Commons in Parliament. He divided the arguments he meant to oppose into two kinds. First there was the claim that representation was the natural right of the individual, and it was in answering this that Burke used the following words:

Our constitution is a prescriptive constitution; it is a constitution whose sole authority is that it has existed time out of mind.... Your king, your lords, your judges, your juries, grand and little, all are prescriptive; and what proves it is the disputes not yet concluded, and never near becoming so, when any of them first originated. Prescription is the most solid of all titles, not only to property, but, which is to secure that property, to government... .It is accompanied with another ground of authority in the constitution of the human mind-presumption. It is a presumption in favour of any settled scheme of government against any untried project, that a nation has long existed and flourished under it. It is a better presumption even of the choice of a nation, far better than any sudden and temporary arrangement by actual election. Because a nation is not an idea only of local extent, and individual momentary aggregation; but it is an idea of continuity, which extends in time as well as in numbers and in space. And this is a choice, not of one day, or one set of people, not a tumultuary and giddy choice; it is a deliberate election of ages and generations; it is a constitution made by what is ten thousand times better than choice, it is made by the peculiar circumstances, occasions, tempers, dispositions, and moral, civil and social habitudes of the people, which disclose themselves only in a long space of time. It is a vestment, which accommodates itself to the body. Nor is prescription of government formed upon blind, unmeaning prejudices-for man is a most unwise and a most wise being. The individual is foolish; the multitude, for the moment, is foolish, when they act without deliberation; but the species is wise, and, when time is given to it, as a species it always acts right. ${ }^{27}$

Now these sentences (though never spoken by their author) are treasured in the anthologies of English conservatism and repeated in nearly every textbook on the history of political thought; but the meaning which they had for Burke and his intended auditors can be appreciated only when we regard them as a restatement of the classic and familiar doctrine of the ancient constitution, in which its two fundamental assumptions are brought out and elaborated. Burke's prescriptive constitution has two characteristics: it is immemorial-and this is what makes it prescriptive and gives it authority as a constitution-and it is customary, rooted in something 'better than choice...the peculiar circumstances... and ... habitudes of the people'. This is Burke's argument against a reform of the representation founded upon the principle of natural right. Every word he uses may be paralleled from the traditional doctrines of the common lawyers, the doctrines he had once rejected in his criticism of Hale but was to espouse once again in the Reflections; and common-law thought, as Burke could have found it in Hale and was

${ }^{26}$ The speech does not occur in Hansard. In the editions of Burke's collected works it appears in an incomplete form.

${ }^{27}$ Burke, loc. cit. I46-7. 
(wherever he learned it) expounding it here, contained an explicitly formulated theory of conservative traditionalism.

Was Burke an antiquarian, expounding seventeenth-century ways of thinking to a generation of uncomprehending Lockeans? This conclusion easily follows from some of the unstated assumptions upon which the history of ideas is commonly conducted, ${ }^{28}$ but it can be disproved by the simple exercise of observing how Burke's draft of May 1782 develops. There is, he says, a second argument in favour of reform, which he now proceeds to answer in the same way as the argument based on natural right; and it consists in the assertion that the constitution has fallen away from its original principles-here supposed to include the principle of representation on the basis of numbers-and must now be restored to them. This argument Burke answers with an assertion of startling simplicity and yet venerable antiquity-one implicit in the debate between Hale and Hobbes; that an immemorial constitution is not based upon any original principles and that consequently none can be alleged as a means of evaluating its workings.

To ask whether a thing which has always been the same stands to its usual principle, seems to me to be perfectly absurd; for how do you know the principles but from the construction? and if that remains the same, the principles remain the same. It is true, that to say your constitution is what it has been is no sufficient defence for those who say it is a bad constitution. It is an answer to those who say it is a degenerate constitution....

On what grounds do we go to restore our constitution to what it has been at one definite period, or to reform and reconstruct it upon principles more conformable to a sound theory of government? A prescriptive government, such as ours, never was the work of any legislator, never was made upon any foregone theory. It seems to me a preposterous way of reasoning, and a perfect confusion of ideas, to take the theories which learned and speculative men have made from that government, and then, supposing it made on those theories, which were made from it, to accuse the government as not corresponding with them. ${ }^{29}$

The sentiments of the second paragraph can be rediscovered in Professor Oakeshott's Political Education, ${ }^{30}$ but the passage as a whole might have been written by Hale. The requirements which the constitution has existed to satisfy can only be inferred from its structure, and if the structure is immemorial nothing can be inferred about its functioning at any particular time. Consequently, we can never know the principles on which it has functioned, either at its origin or at any subsequent period; and only by partial and speculative abstraction can we discover any principles which we may

${ }^{28}$ It is easy, for reasons glanced at earlier in this paper, to think of Locke as if he transformed the whole character of English political thinking and inaugurated a period in which it was conducted exclusively in rationalist terms. The present writer was once led ( $A C F L$, 243) to speak of the customary concept of English law as 'running underground' between Hale and Burke, and an American reviewer developed the idea of a 'rationalist hiatus' in English thought. To such over-simplifications the history of ideas seems prone.

${ }_{29}$ Burke, loc. cit. 148 .

30 P. Laslett (ed.), Philosophy, Politics and Society (Oxford, 1956), 7-10. 
call common to its entire history. Its true basis, moreover, will not lie in these principles but in the mere fact of prescription. Burke, in fact, has reverted to the position he formerly rebuked Hale for adopting-that little or nothing can be known of the history of an immemorial constitution save that there is a great weight of presumption in its favour; and like Hale, he roots his argument in the idea that the law is immemorial and customary.

He developed this argument as a reply to the contention that the constitution had degenerated from its original principles. This doctrine was indeed employed by Pitt and other speakers for the motion of May 1782 , and is a staple argument in the literature of the county movement. It may be traced back through James Burgh to Bolingbroke, and on through Major Cartwright and the literature of the next half-century of frustrated reformers. ${ }^{31}$ Its importance for our purposes is that it was clearly no more than a partial rationalization of the traditional common-law doctrine. There exists an ancient constitution, it said, whose claim upon us lies largely in its antiquity; but this constitution was founded upon principles which can be known, and we are therefore able to know when it has degenerated from them and to restore it to them. This Burke denied. He was, therefore, faced not only with a rationalist doctrine based on a Lockean theory of natural right, but also with a modified form of the seventeenth-century 'ancient constitution'. It emerges that a political language was still in regular use in 1782 , based on assumptions which had been established in English thought as far back as the age of Coke by the theory and practice of the common law and had notas it is too easy to suppose they had-been submerged in a tide of rationalism.

In the conflicting ideologies of the first period of parliamentary reform it is possible to discern reaffirmations of a number of typical seventeenth-century ideas. For example, Leveller anti-Normanism-the doctrine that existing laws and institutions are unjust, being founded in Norman conquest and usurpation-reappears in Paine and Cartwright; and it has been argued elsewhere ${ }^{32}$ that there is no need to suppose direct contact or transmission between the ideas of 1648 and 1780 . In both periods it was usual to declare that the essential soundness of the laws was proved by their having survived the Conquest, and it is not to be wondered at if the same affirmation called forth the same negation; Overton, Paine and their adversaries all spoke the same language. Burke, too, was in the part of his thought under inspection repeating the assumptions of the seventeenth century. Faced with an argument for reform that presupposed the existence of an ancient constitution, he responded by pointing out the foundation on which that belief was really based: the identification of law with immemorial custom, from which it was possible to deduce an entire philosophy of sceptical conservatism and empirical tra-

${ }^{31}$ H. Butterfield, George III, Lord North and the People (1949), 34I-52; Christopher Hill, Puritanism and Revolution (1958), ch. III, 'The Norman Yoke', 94-122.

${ }^{32} A C F L, 127$. 
ditionalism. Hale had deduced that philosophy and Burke, who also deduced it, was acquainted with part of Hale's work and had criticized it for the very positions he was afterwards to take up. But the present essay is not designed to show that Hale 'influenced' Burke or that Burke 'derived' his ideas from Hale; such phraseology is universally agreed to be inadequate. If any importance attaches to Burke's readings in the ancient-constitution thought of the previous century, it may be that they helped to create his intense historical awareness of the common-law tradition as "the stationary policy of this kingdom'-as a factor in shaping English political thought and behaviour. The point which it seems most important to establish is that Hale and Burke reached similar conclusions because they were arguing from similar assumptions, from a common acceptance of a belief in immemorial customary law which, as Burke found it necessary to explain and Hale did not, was one of the cardinal beliefs of the society and tradition in which both men lived. Burke's traditionalism is rooted in a way of thought already traditional; it may be possible to discern, from the way in which he restated it, that it was a tradition beginning to fade.

It is important that this analysis should not seem to claim too much. It is confined to one aspect of Burke's thought-his doctrine of the superior wisdom of traditional institutions-and it treats even that in isolation. There are many things in his social and political philosophy besides his traditionalism, and it is not suggested that his membership of the common-law tradition explains all or any of them. To understand their meaning and their presence among his ideas, it may well be necessary to invoke the natural law, the philosophy of Hume, the sociology of Montesquieu or the rise of a romantic sensibility, and even more complex operations will obviously be needed if any one aspect of his thought is to be reduced to philosophical unity with any other. It is certainly not suggested that Burke's unified view of realityif he had one-was derived from the common law; on the other hand it is suggested that in order to explain his traditionalism, regarded simply as an isolated factor, there is no need to suppose more than his continued employment and highly developed understanding of certain concepts which came from the common law (as he recognized) and were generally in use as part of the political language he spoke with his contemporaries. In this respect, Burke's thought was formed by the contemplation of English society and history with the aid of concepts traditionally used for that purpose, and by the contemplation of those concepts themselves. 